\title{
Cytochrome P450 11B2, Mitochondrial
}

National Cancer Institute

\section{Source}

National Cancer Institute. Cytochrome P450 11B2, Mitochondrial. NCI Thesaurus. Code C40064.

Cytochrome P450 11B2, mitochondrial (503 aa, 58 kDa) is encoded by the human CYP11B2 gene. This protein plays a role in corticosterone metabolism. 